\title{
Optimization of shale gas reservoir evaluation and assessment of shale gas resources in the Oriente Basin in Ecuador
}

\author{
Hong Zhang ${ }^{1} \cdot$ Jun-Tai Shi ${ }^{1} \cdot$ Xiang-Fang $\mathrm{Li}^{1}$
}

Received: 19 September 2017 / Published online: 22 October 2018

(C) The Author(s) 2018

\begin{abstract}
The petroleum geological features of hydrocarbon source rocks in the Oriente Basin in Ecuador are studied in detail to determine the potential of shale gas resources in the basin. The favorable shale gas layer in the vertical direction is optimized by combining logging identification and comprehensive geological analysis. The thickness in this layer is obtained by logging interpretation in the basin. The favorable shale gas accumulation area is selected by referring to thickness and depth data. Furthermore, the shale gas resource amount of the layer in the favorable area is calculated using the analogy method. Results show that among the five potential hydrocarbon source rocks, the lower Napo Formation is the most likely shale gas layer. The west and northwest zones, which are in the deep-sea slope and shelf sedimentary environments, respectively, are the favorable areas for shale gas accumulation. The favorable sedimentary environment formed thick black shale that is rich in organic matter. The black shale generated hydrocarbon, which migrated laterally to the eastern shallow water shelf to form numerous oil fields. The result of the shale gas resource in the two favorable areas, as calculated by the analogy method, is $55,500 \times 10^{8} \mathrm{~m}^{3}$. This finding shows the high exploration and development potential of shale gas in the basin.
\end{abstract}

Keywords Ecuador · Oriente Basin · Shale gas · Optimization · Analogy method · Amount of resources

\section{Introduction}

The Oriente Basin is a foreland basin in the transition zone between the tectonically active Cordillera region and the stable Brazil-Guiana Shield (Christophoul et al. 2002). As one of the largest oil-producing basins in the South Andean foreland basin, the Oriente Basin accounts for $97 \%$ of the proven reserves in Ecuador (Ma et al. 2014). The oil- and gas-producing capabilities of this basin have always attracted the attention of scholars. Two opinions prevail about the source rock of the Oriente Basin. One idea assumes that the main hydrocarbon source rocks of the basin (potential shale reservoir) are the Cretaceous group Napo marine shale and carbonate (Xie et al. 2010;

Edited by Jie Hao

Hong Zhang

zhang_ho_2002@sina.com

1 School of Petroleum Engineering, Key Laboratory of Petroleum Engineering of the Ministry of Education, China University of Petroleum, Beijing 102249, China
Dashwood and Abbotts 1990). Meanwhile, others believe that the oil and gas come from the Santiago Formation (Gaibor et al. 2008). The general perspective is that the oil and gas are generated from the Napo marine shale in the north and Santiago Formation in the south and east of the basin. The main reservoirs are the Cretaceous group Hollin and Napo Formation sandstones (Estupiñan et al. 2010). The Cretaceous group is a source bed and an oil reservoir. The probable main seal rocks for Napo Formation are interbedded and overlying marine shales. The exploration and production data indicate that the Oriente Basin mainly produces oil and natural gas and yields considerably more of the former than the latter. To date, scholars have performed minimal research on the natural gas resource potential of this basin.

The Ecuador government and local petroleum workers encounter difficulties in searching for natural gas reservoirs and increasing the output of natural gas. One possibility is exploring for a natural gas resource in the Cretaceous strata, which have high organic matter content and high hydrocarbon generation potential. The USA has, for example, made significant achievements in shale gas 
development. Meanwhile, identifying possible Shale Gas Formations and evaluating the amount of shale gas resources on the basis of the original exploration and exploitation activities are the most effective means of exploring the natural gas resources which remain unexplored in the Oriente Basin, Current approaches include combining geological qualitative analysis with quantitative logging interpretation to identify the shale gas layer. Then, logging interpretation results are combined with seismic analysis results to study the characteristics of target shale thickness and determine the reasons for thickness variation. In this manner, the most favorable shale gas accumulation blocks are identified, and their resources are ultimately calculated.

\section{Geological setting}

The Oriente Basin is a back-arc foreland basin that is adjacent to the Putumayo Basin in Colombia and the Maranon Basin in Peru (Ma et al. 2014). The north, south, west, and east parts are high, low, thick, and thin, respectively. The sedimentary sequence thins from west to east and overlaps the Guiana Shield; the sedimentary center is in the northernmost part of Peru. The sedimentary filling of the Oriente Basin is from the Paleozoic era to the present. The Pumbuiza Formation from the Upper Silurian to the Lower Carboniferous is the oldest stratum found through drilling. The Mesozoic strata can be divided into Triassic Santiago, Jurassic Chapiza and Cretaceous Hollin, Napo, and Tena Formations. The Santiago Formation comprises a transgressive thin layer of carbonate and black bituminous shale. The Lower Cretaceous Hollin Formation was deposited during the early Cretaceous transgression. On top of the Hollin Formation is the Napo Formation, which is the main object of this study. The Napo shale unconformity covers the upper Hollin Formation and is covered by the Tena Formation. The Napo Formation is the main oil and gas unit of the Oriente Basin and contains the largest amount of hydrocarbon source rocks. This Formation, whose thickness ranges from 200 to $700 \mathrm{~m}$, contains organic-rich marine black shale, clastic rocks, clay grains, and sandstone. In addition, the Napo Formation can be divided into the lower, middle, and upper Napo Formations. The lower Napo Formation, which is the target layer of this study, contains continuous sandstone, shale, and limestone, and its thickness reaches $300 \mathrm{~m}$. The middle Napo Formation, whose thickness reaches $100 \mathrm{~m}$, is dominated by clastic rocks and shale, followed by sandstone. During the lower and middle Napo Formation sedimentary periods, the depositional environment was deepsea slopes and shelf sedimentary areas. The organic-matterrich marine black shale deposit, the most important source rock of the basin, was formed (Brookfield et al. 2009; Ma et al. 2017). The upper Napo Formation mainly contains shale, followed by limestone and sandstone; its thickness reaches $250 \mathrm{~m}$. Two sets of transgressive-regressive cycles occur from the bottom of the lower Napo Formation to the middle Napo Formation. These transgressive-regressive cycles have formed $\mathrm{T}, \mathrm{U}$, and $\mathrm{M}$ sandstone units. The $\mathrm{T}$ and $\mathrm{U}$ sandstone sequences have the same composition, i.e., both are layered sandstone, mudstone, and fossil limestone. The uppermost layer of the sequences comprises M1 and M2 clastic quartz rocks, which form the most important reservoirs in the basin (Torres et al. 2010; Brookfield et al. 2009).

\section{Optimization of shale gas layer in Oriente Basin}

\subsection{Comprehensive evaluation of geology}

Shale gas is unconventional natural gas stored in its own reservoir. A shale gas reservoir, which can be used as an exploitation target, requires certain conditions. Shale reservoirs are effective hydrocarbon source rocks that require high organic carbon content and an appropriate stage of thermal evolution. Accumulated thickness must reach $15 \mathrm{~m}$ to contain enough resource, and the depth of shale must be $<4000 \mathrm{~m}$ to achieve commercial development value. A shale gas reservoir is tight; thus, fracturing is necessary. Accordingly, the general requirement for brittle mineral content in shale must be higher than $30 \%$ to obtain a good fracturing effect. Shale reservoirs are tight and can effectively produce gas under certain physical conditions, i.e., permeability should be higher than 100nd, and porosity should be higher than $2 \%$. Moreover, shale gas reservoirs for development should have a certain degree of exploration and relatively complete basic research data. These reservoir parameter criteria are summarized from several

Table 1 Development conditions of a shale gas reservoir

\begin{tabular}{ll}
\hline Index & Value \\
\hline TOC & $>2 \%$ \\
$R_{\mathrm{o}}$ & $>0.5 \%$ \\
Depth & $<4000 \mathrm{~m}$ \\
Accumulated thickness & $>15 \mathrm{~m}$ \\
Brittle mineral content & $>30 \%$ \\
Permeability & $>100 \mathrm{nd}$ \\
Porosity property & $>2 \%$ \\
Research data integrity & Drilling into layer, outcrop rich \\
\hline
\end{tabular}


actual shale gas production layers in the USA (Curtis 2002; Xiao et al. 2015; Table 1).

The geological structure of the Oriente Basin has experienced long and complex evolution. Different degrees of development of shale layers have occurred at various stages of tectonic evolution. Five sets of strata (from bottom to top), namely the Macuma Formation in the Paleozoic strata; the Santiago Formation, lower Napo shale layer, and middle Napo shale layer in the Mesozoic strata; and the Tiyuyacu Formation in the Paleogene strata, are potential shale gas reservoirs. In accordance with the standards shown in Table 1, five sets of Shale Formations are studied (Table 2). The depths of the Macuma and Santiago Formations are more than $5000 \mathrm{~m}$ and approximately $4000 \mathrm{~m}$, respectively. Moreover, the Santiago Formation is mainly distributed in the southern part of the basin and lacks complete drilling data (Gaibor et al. 2008). Thus, the Macuma and Santiago Formations have no development value and cannot be used as favorable shale gas reservoirs. Although the shales in the Tiyuyacu Formation are relatively shallow and easy to explore, the organic carbon content and the degree of thermal evolution of the shales are low. Hence, the shales in the Tiyuyacu Formation have no hydrocarbon generation capability. The burial depth and thermal evolution of the middle Napo shales in the Mesozoic strata are moderate; however, the distribution stability in the entire basin is poor, and the depth of the middle Napo shales is shallower than that of the lower Napo group (Ma et al. 2017). Thus, the middle Napo layer cannot be used as a favorable shale gas reservoir. By contrast, the burial depth of the lower Napo shales in the Mesozoic strata is moderate. Organic matter is rich, and the average TOC value for the entire basin is $4.7 \%$, with $R_{\mathrm{o}}=0.4 \%-0.6 \%$. There are two types of shale gas. One type is biogenic shale gas, and the other type is thermally formed. The biogenic shale gas needs low vitrinite reflectance $\left(R_{\mathrm{o}}\right)$ (Song et al. 2015). The Antrim and the New Albany Shale gas of America belong to this type, and their $R_{\mathrm{o}}$ values are $0.4 \%-0.6 \%$ and $0.4 \%-1.0 \%$. Thus, the shales of lower Napo shales are in the threshold of biogenic shale gas (Fig. 1). This layer has rich research data obtained from drilling. Several outcrop sections are also available (Table 2). The lower Napo shale layer can be regarded as the most favorable shale gas reservoir on the basis of a comprehensive consideration of the geological evaluation of hydrocarbon generation capacity, exploration and development difficulty, distribution stability, and data integrity (Table 2).

\subsection{Well logging identification and optimization}

In this study, the possible enrichment layer of shale gas in the vertical direction is provided by using the actual geological data of the Oriente Basin via comprehensive geological analysis. The subsequent studies are quantitatively validated via logging interpretation. Geologists and reservoir development engineers regard logging technology as an efficient and economical method for identifying shale gas reservoirs and thus an important approach for oil and gas exploration. The physical properties of a Formation can be directly obtained from a borehole using logging data. Lithology, mineral composition, and organic matter content can be determined through interpretation and evaluation. A shale gas reservoir can be identified by analyzing

Table 2 Five sets of potential source rock parameters in Oriente Basin

\begin{tabular}{|c|c|c|c|c|c|c|c|}
\hline Shale layer & TOC & $R_{\mathrm{o}}$ & Depth, m & $\begin{array}{l}\text { Accumulated } \\
\text { thickness, m }\end{array}$ & $\begin{array}{l}\text { Brittle } \\
\text { mineral } \\
\text { content }\end{array}$ & $\begin{array}{l}\text { Physical } \\
\text { property }\end{array}$ & Research data integrity \\
\hline $\begin{array}{l}\text { Macuma } \\
\text { Formation }\end{array}$ & No data & No data & $>5000$ & No data & No data & No data & $\begin{array}{l}\text { No drilling well and } \\
\text { seismic data }\end{array}$ \\
\hline $\begin{array}{l}\text { Santiago } \\
\text { Formation }\end{array}$ & $2 \%-5 \%$ & $\begin{array}{l}0.5 \%- \\
1.35 \%\end{array}$ & $>4000$ & $20-30$ & $>30 \%$ & No data & $\begin{array}{l}\text { No drilling well and } \\
\text { seismic data, some } \\
\text { outcrops }\end{array}$ \\
\hline $\begin{array}{l}\text { Lower Napo } \\
\text { shale layer }\end{array}$ & $4.7 \%$ (average) & $\begin{array}{r}0.4 \%- \\
0.6 \%\end{array}$ & $2700-3500$ & $15-20$ & $39 \%$ & $\begin{array}{l}\varphi: 3 \%- \\
5 \%\end{array}$ & \\
\hline$K:<0.1 \mathrm{md}$ & $\begin{array}{l}\text { Numerous data, including well, } \\
\text { seismic, and outcrop data }\end{array}$ & & & & & & \\
\hline $\begin{array}{l}\text { Middle Napo } \\
\text { shale layer }\end{array}$ & $4 \%$ (average) & $\begin{array}{r}0.4 \%- \\
0.5 \%\end{array}$ & $2600-340$ & $20-30$ & $36 \%$ & $\begin{array}{l}\varphi: 3 \%- \\
5 \%\end{array}$ & \\
\hline$K:<0.1 \mathrm{md}$ & $\begin{array}{l}\text { Numerous data, including well, } \\
\text { seismic, outcrop data }\end{array}$ & & & & & & \\
\hline $\begin{array}{l}\text { Tiyuyacu } \\
\text { Formation }\end{array}$ & $<2 \%$ & $<0.4 \%$ & 1200 & $20-30$ & No data & No data & Well and seismic data \\
\hline
\end{tabular}




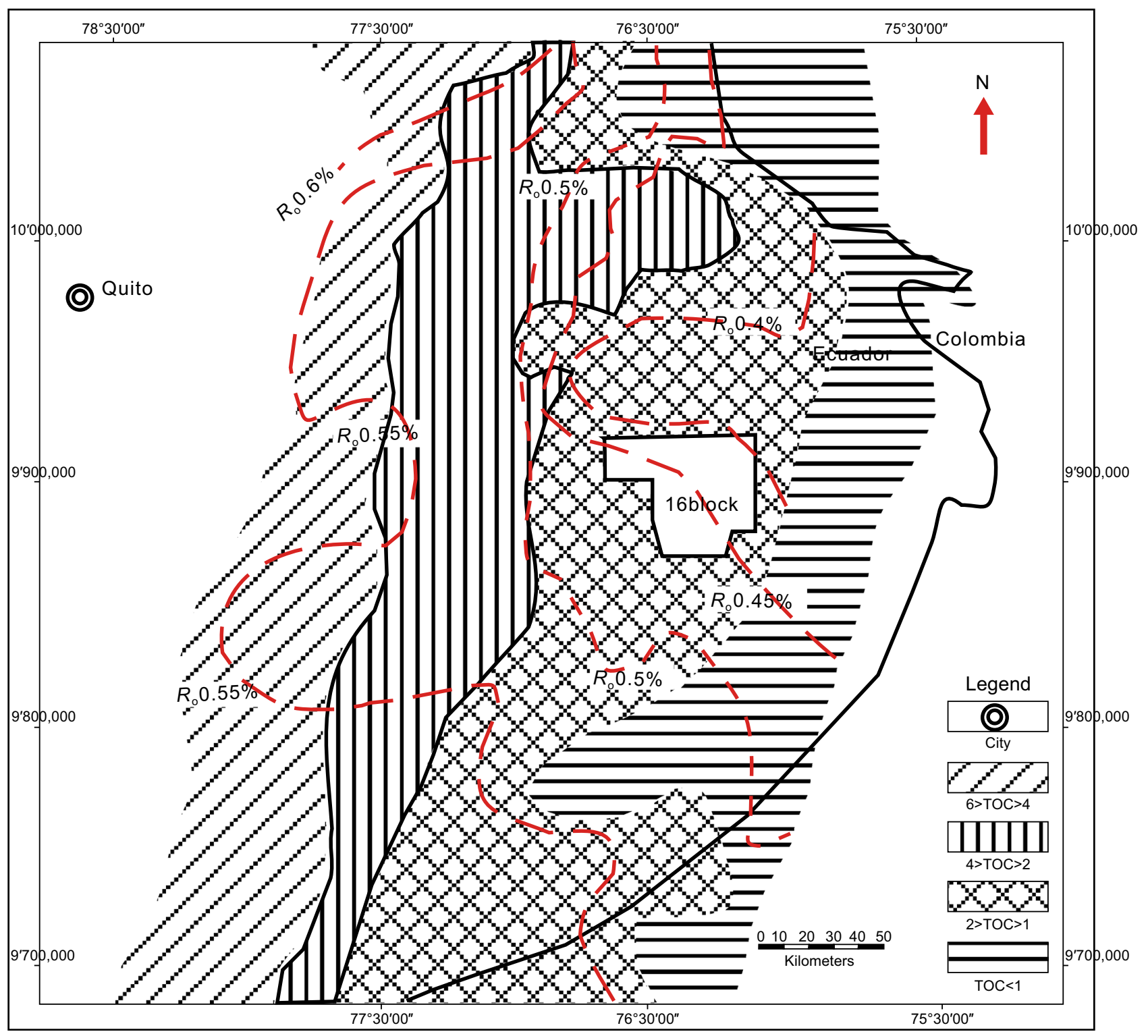

Fig. 1 Geochemical features of Napo Formation source rock (Dashwood and Abbotts 1990)

logging data. Scholars and oil workers worldwide have identified shale gas reservoirs using logging technologies, such as logging while drilling (LWD), imaging logging, and LWD sonic logging. Several problems are encountered in identification, such as complex analysis procedures, high technical requirements, high investment cost, and lack of simple and practical analysis methods. A semi-quantitative summary of the logging response characteristics of shale gas reservoirs has been prepared on the basis of a large number of domestic and foreign studies on identifying shale gas reservoirs using logging technology (Yan et al. 2014).

\subsubsection{Logging response characteristics of shale gas}

The shale layer contains organic matter that generates biogenic gas under the action of anaerobic organisms. In addition, organic matter forms kerogen, which is a major source of hydrocarbons, under the influences of temperature and pressure. The lithology of shale is mostly asphaltene, which is dark and black shale that is rich in organic matter or high-carbon shale. Clay mineral and organic matter contents are high in shale content. A reservoir is tight and has low porosity; thus, fractures frequently develop. The organic carbon content of shale gas layers can reach 10-20 times that of common hydrocarbon source rocks and ranges from $0 \%$ to $25 \%$. Through a review and investigation of the literature (Yang et al. 
2012), the logging response characteristics of shale gas reservoirs are summarized in Table 3.

In shale gas reservoirs, the response of caliper logging exhibits enlargement and that of spontaneous potential (SP) logging shows the base value. The gamma ray (GR) logging value is high, the density logging value is low, the acoustic logging value is high, and the resistivity logging value ranges from median to high. The GR and resistivity logging values increase with organic matter and hydrocarbon contents.

\subsubsection{Identification and optimization of shale gas layer in Oriente Basin}

To compile the logging data statistics of 19 typical wells in the Oriente Basin, the logging response characteristics of shale gas reservoirs are adopted and logging features are combined to identify shale gas reservoirs (Table 4). The logging curves of only two wells are selected to analyze the identification process given the limited length of this paper. Figure 2a, b shows the log curves of the Guallino- 1 and Masaramu-1 wells, respectively. These figures indicate the logging response characteristics of the middle and lower Napo shales of the Guallino-1 well. The caliper logging exhibits enlargement, the SP logging shows the base value, the GR logging value is high at 100-110 API, the acoustic logging value is $80 \mu \mathrm{s} / \mathrm{ft}$, and the resistivity logging value is high at $120-200 \Omega \mathrm{m}$. In particular, the resistivity logging value of the lower Napo Formation is $200 \Omega \mathrm{m}$. Therefore, the middle and lower Napo Formations of Guallino-1 fully satisfy the logging response characteristics of shale gas reservoirs. For the middle and lower Napo shales of Masaramu-1, the response characteristics of caliper, SP, GR, acoustic, and resistivity logging also satisfy the logging response characteristics of shale gas reservoirs. In addition, a comparison of the logging response characteristics of the middle and lower Napo shales shows that the GR and resistivity logging values of lower Napo shale are higher than those of the middle Napo shale of Guallino-1. Meanwhile, for Masaramu-1, the GR logging value of lower Napo shale is higher than that of the middle Napo shale. When the organic matter and kerogen contents in a reservoir are high, the values of GR and resistivity logging are also high. Therefore, the lower Napo shale has higher organic matter content and gas-bearing potential than the middle Napo shale. The lower Napo shale Formation is selected as the most favorable shale gas layer in the longitudinal direction on the basis of the preceding analysis. Other wells in Table 4 show similar logging response characteristics to the middle and lower Napo shales. In summary, results of the comprehensive geological analysis and quantitative logging identification show that the lower Napo shale Formation is the potential favorable shale gas layer.

\section{Identification of most favorable shale gas accumulation areas}

\subsection{Identification of favorable areas}

In accordance with the aforementioned logging identification results of shale gas reservoirs and the logging response characteristics of the lower Napo Formation in this area, the shale thickness of the lower Napo Formation of 38 wells in different blocks of the Oriente Basin is explained (Table 5). In addition, a contour map of the thickness distribution is provided (Fig. 3).

Table 5 and Fig. 3 show that the target shale is widespread in the basin, and its thickness is approximately $15-25 \mathrm{~m}$. The vicinities of blocks 18 and 81 in the northwest and southwest parts of the basin, respectively, have a deposition center. The deposition center reduces near blocks 58 and 17 in the northern and middle parts of the basin, respectively. Thus, the shale thickness gradually reduces from west to east.

Favorable areas must be screened for shale gas exploration and development in the horizontal direction when considering the feasibility of practical exploration. Figure 4 shows that the Oriente Basin is divided into six regions on the basis of geographical position: northwest, west, east, south, north, and central regions. The feasibility of exploration and development in different regions is analyzed, and the favorable exploitation area is identified by combining well logging and seismic data and by considering the thickness, depth, and change in thickness of the lower Napo Formation in the target layer.

Table 3 Logging curve characteristics of shale gas reservoirs

\begin{tabular}{lllllll}
\hline Logging method & Caliper logging & $\begin{array}{l}\text { SP logging, } \\
\mathrm{mV}\end{array}$ & $\begin{array}{l}\text { GR logging, } \\
\text { API }\end{array}$ & $\begin{array}{l}\text { Density logging, } \\
\mathrm{g} / \mathrm{cm}^{3}\end{array}$ & $\begin{array}{l}\text { Acoustic logging, } \\
\mu \mathrm{s} / \mathrm{ft}\end{array}$ & $\begin{array}{l}\text { Resistivity logging, } \\
\text { ohm m }\end{array}$ \\
\hline $\begin{array}{c}\text { Response } \\
\text { characteristic }\end{array}$ & $\begin{array}{c}\text { Hole } \\
\text { enlargement }\end{array}$ & Normal value & $100-1000$ & $2.42-2.65$ & $60-100$ & $\geq 100$ \\
\hline
\end{tabular}




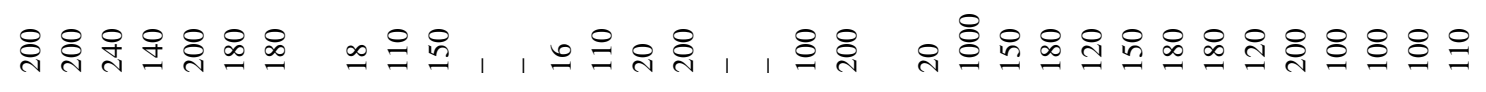
\& \&용ㅇㅁ

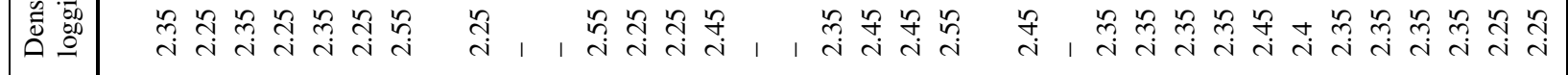
$\overline{\mathrm{z}}$

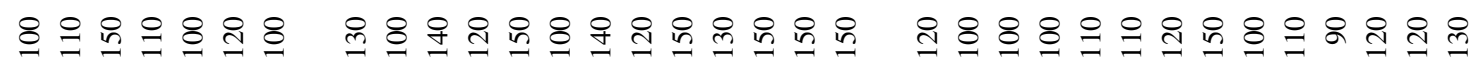
7

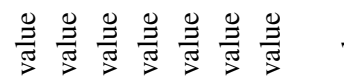

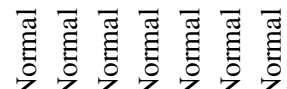

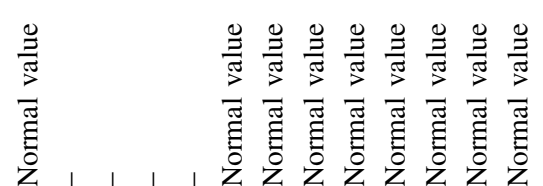

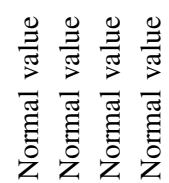

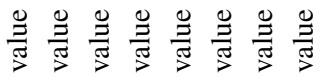
云云云云安

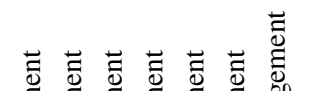

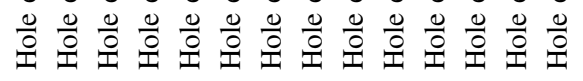

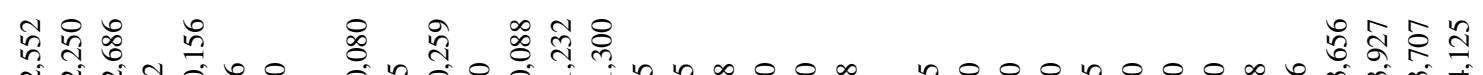

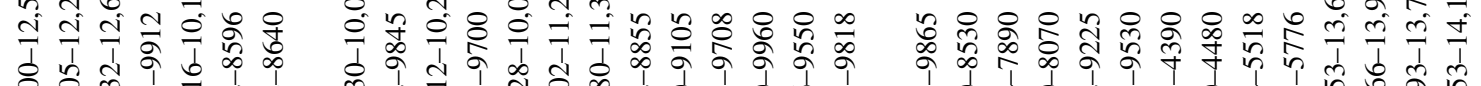

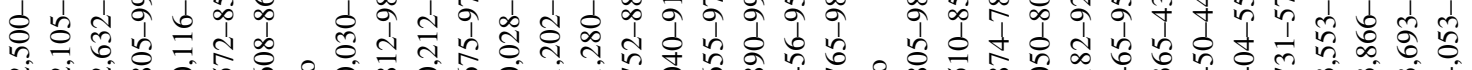

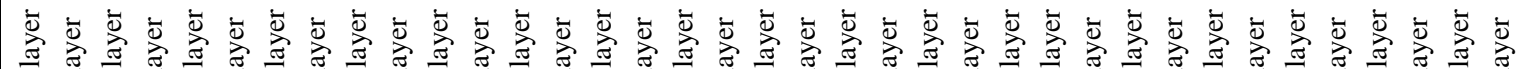

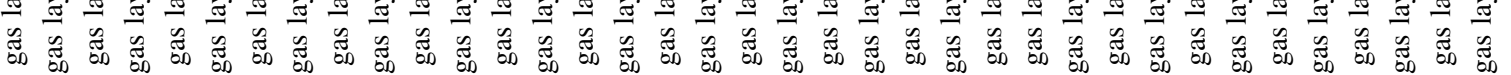

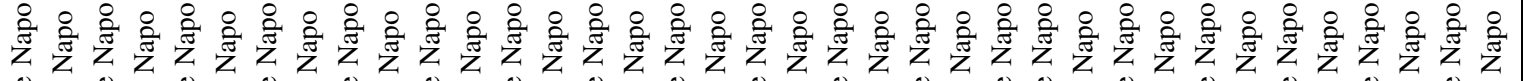

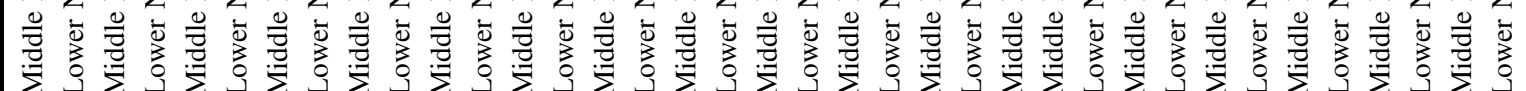

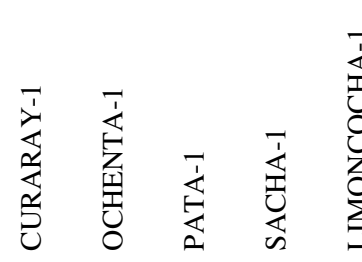

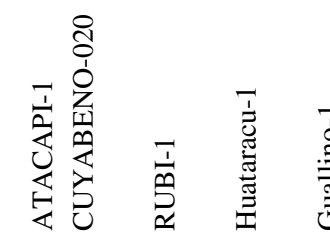

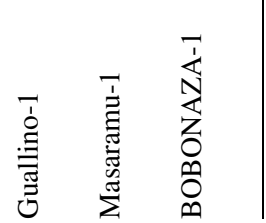




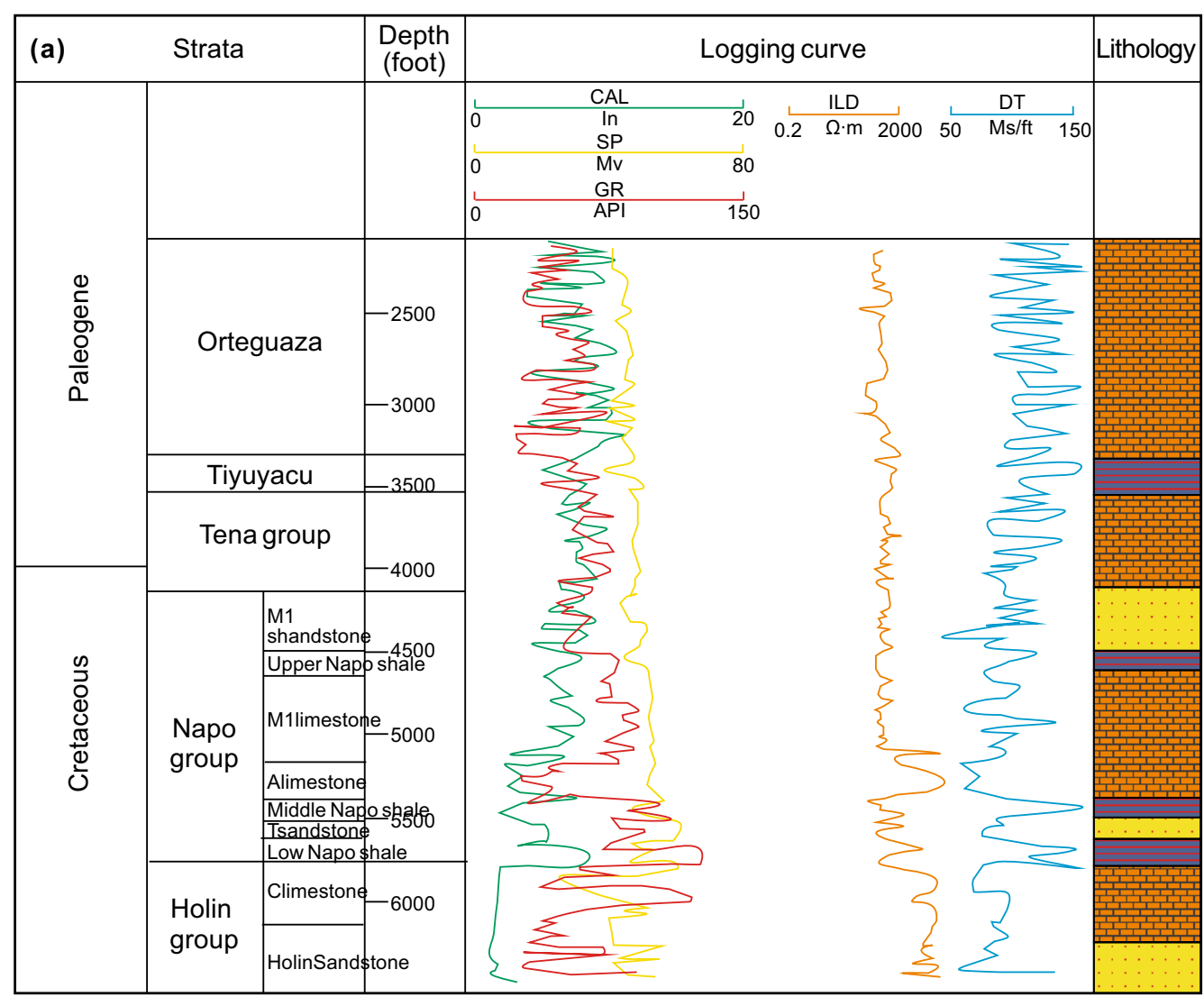

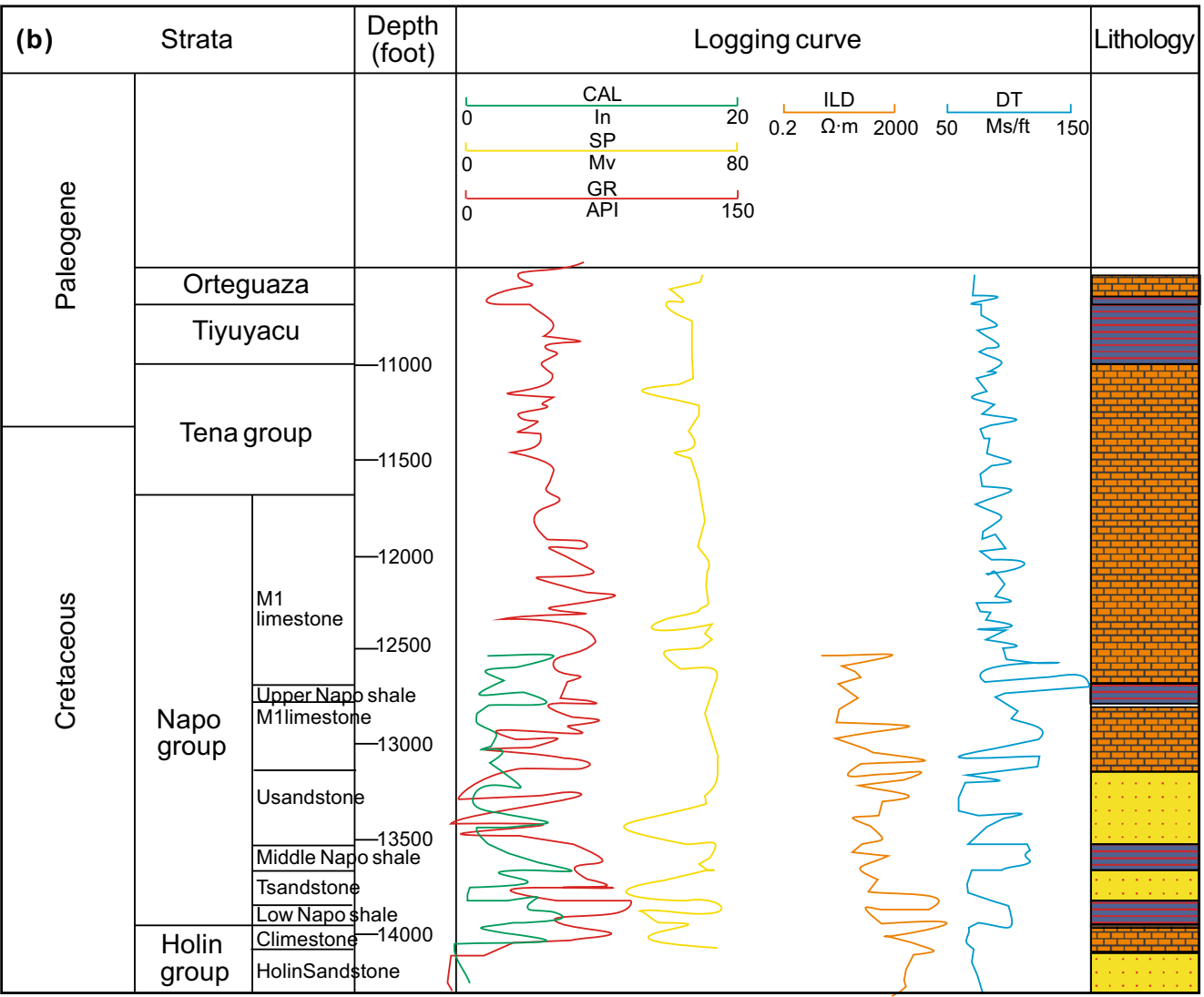

Fig. 2 Log curve of Guallino-1 well (a) and Masaramu-1 well (b) 
Table 5 Thickness of lower Napo shale in Oriente Basin

\begin{tabular}{|c|c|c|}
\hline Well & Block & Thickness, ft \\
\hline AMAZONAS-1 & 86 & $45(9985-10,030)$ \\
\hline AUTAPI-1 & 28 & 45 (6905-6950) \\
\hline BALSAURA-1 & 86 & $40(10,116-10,156)$ \\
\hline DANTA-1 & 83 & $54(12,632-12,686)$ \\
\hline COCA-1 & 17 & 67 (9320-9387) \\
\hline DANTA-2 & 83 & $65(12,820-12,885)$ \\
\hline Garza-1 & 83 & $38(12,282-12,320)$ \\
\hline Guallino-1 & 70 & 45 \\
\hline Huito_001 & 86 & 68 (9924-9992) \\
\hline Manati-1 & 80 & $54(12,568-12,622)$ \\
\hline Marañon-1 & 86 & $60(10,120-10,180)$ \\
\hline Masaramu-1 & 79 & $61(13,866-13,927)$ \\
\hline NASHIÑO-1 & 31 & $62(7578-7640)$ \\
\hline RAMIREZ-1 & 83 & $42(12,520-12,562)$ \\
\hline Tigrillo-1 & 80 & $53(12,230-12,283)$ \\
\hline Tzapino-1 & 22 & $52(9820-9872)$ \\
\hline Limoncocha-001 & 15 & $60(9800-9860)$ \\
\hline PUCUNA-1 & 44 & $60(9670-9730)$ \\
\hline CHARAPA-001 & 50 & $59(10,047-10,116)$ \\
\hline DURENO-001 & 57 & $58(9964-10,022)$ \\
\hline SHUSHUFINDI-001 & 56 & 44 (9330-9374) \\
\hline CUYABENO-020 & 58 & 0 \\
\hline OCHENTA-1 & 11 & 65 (9040-9105) \\
\hline PATA-1 & 18 & 70 (9890-9960) \\
\hline SACHA-1 & 53 & 53 (9765-9818) \\
\hline LIMONCOCHA-1 & 15 & 55 (9805-9865) \\
\hline EDEN-1 & 12 & $63(7560-7623)$ \\
\hline Moretecocha-1 & 10 & $52(12,500-12,552)$ \\
\hline FANNY-1 & 62 & $32(8608-8640)$ \\
\hline YUCA-010 & 64 & $50(10,030-10,080)$ \\
\hline PALANDA-1 & 64 & $45(10,212-10,259)$ \\
\hline AUCA-1 & 61 & $60(10,028-10,088)$ \\
\hline CURARAY-1 & 17 & 0 \\
\hline Masaramu-1 & 79 & $62(13,872-13,934)$ \\
\hline BOBONAZA-1 & 80 & $72(14,053-14,125)$ \\
\hline ATACAPI-1 & 57 & 34 (8564-8598) \\
\hline RUBI-1 & 11 & $65(9465-9530)$ \\
\hline Aguarico-001 & 57 & $42(9570-9612)$ \\
\hline
\end{tabular}

Shale depth in each region is analyzed from the left part to the right part of the basin on the basis of logging data. The shale depth range of the lower Napo Formation in the northwest and west regions is $1357-3037 \mathrm{~m}$, its value remains moderate, and the average thickness is $17.7 \mathrm{~m}$. Shale thickness is large; hence, the northwest and west regions are favorable areas for shale gas exploration. The depth range of the lower Napo shale in the north region is
2454-9865 m, and the average thickness is $9.5 \mathrm{~m}$. The depth range of the lower Napo shale in the central region is $2977-4054 \mathrm{~m}$, and the average thickness is $11.4 \mathrm{~m}$. Burial depth and thickness indicate that the shale thickness of the lower Napo Formation in the north and central regions is too low. Therefore, these regions do not exhibit sufficient exploration potential. The geological setting shows that the basin is high in the north region and low in the south region. The depth of the lower Napo shale in the south region is $4306 \mathrm{~m}$, according to seismic data, and thus greater than that in the north region. The south region is in a deepwater position; hence, it is difficult to explore and cannot be used as a favorable exploration area. Meanwhile, the shale thickness of the east region is thin and does not satisfy the forming conditions of the hydrocarbon source rocks. Therefore, the northwest and west regions are favorable areas for shale gas exploration, according to the preceding analysis of thickness and depth (Fig. 4).

\subsection{Reasons for variation of shale reservoir thickness}

Marine black shale is formed in environments with rapid deposition, closed geological conditions, and high organic matter content. Examples include bench terraces and continental shelves. Formation is typically associated with large-scale water-entry processes. The facies in most areas of the Western Sichuan foreland basin, which is similar to the Oriente Basin, are continental shelf sedimentary. From the west to the east of the basin, the sedimentary facies are archicontinent, littoral, shallow continental shelf, and deepwater continental shelf and slope. The two last facies are strongly reducing sedimentary environments that are conducive to the enrichment of organic matter. The closer to the deep sea, the less shale quartz minerals are enriched, the higher the clay mineral content, and the greater the shale thickness (Wu et al. 2014). These findings are attributed to the lack of oxygen in the deepwater environment of the ocean. Deep and semi-deep seas are rich in organic matter, which is formed by bio-remain deposition and other sources that form black shales (Stow et al. 2001). These carbonaceous shales that are rich in black organic matter can serve as good hydrocarbon source rocks (Jiang et al. 2017). After hydrocarbon generation and expulsion, the deepwater environment of the ocean becomes a favorable shale gas enrichment area (Gross et al. 2015; Misch et al. 2016; Zou et al. 2015). However, not all black shale has the potential for shale oil and gas. If key parameters, such as thermal maturity and saturated hydrocarbon index, do not conform to the characteristics of mature hydrocarbon source rocks, then the potential is limited (Oztürk et al. 2016). The preceding discussion shows that deepwater continental shelves and slopes are 


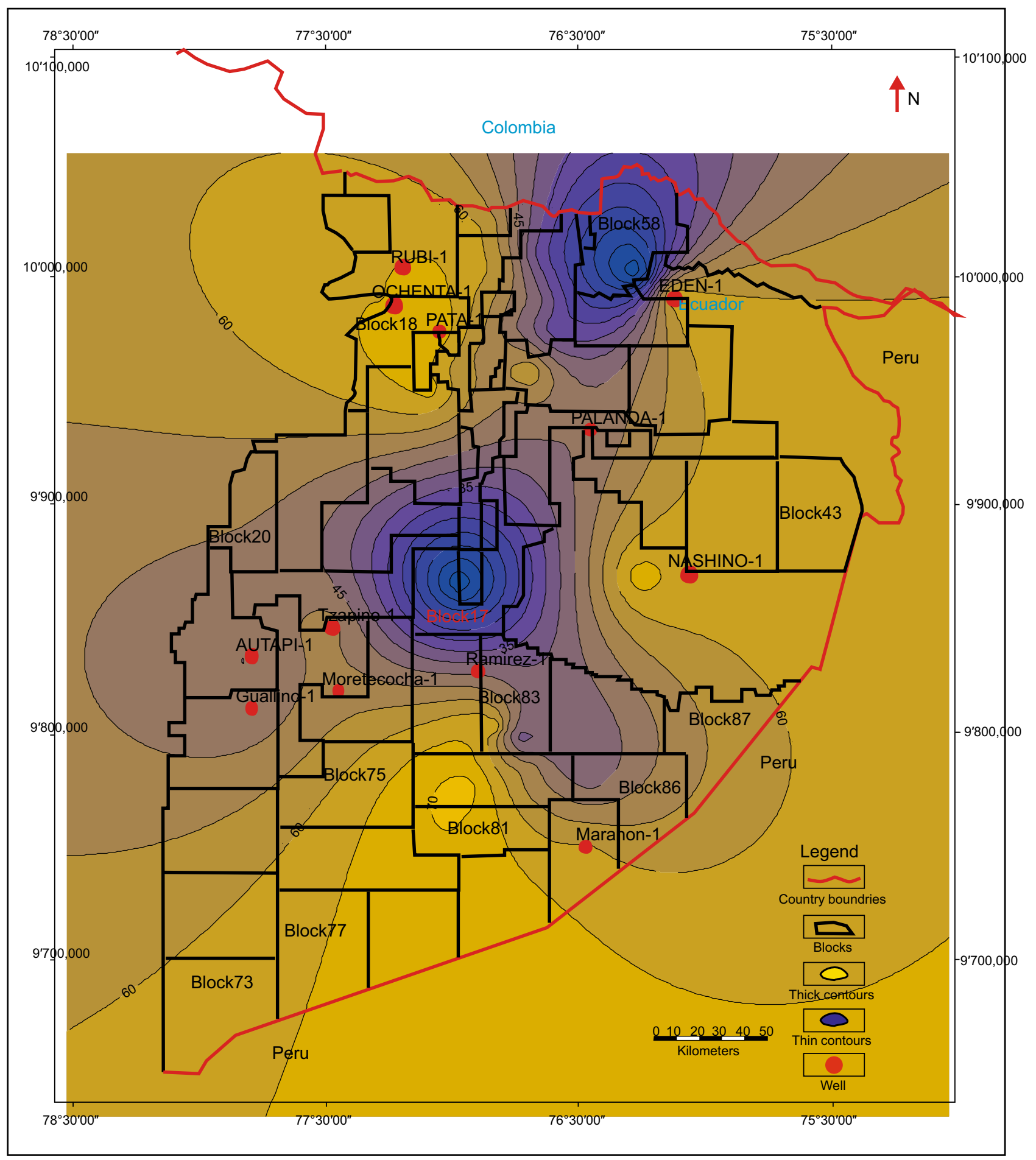

Fig. 3 Contour map of shale thickness distribution in lower Napo Formation in Oriente Basin

favorable environments for the development of dark organic shale. On the basis of the research results of some scholars, the west part of the Oriente Basin was deep and the east part was shallow during the sedimentary period of the Napo group in the Cretaceous era. The northwest part of the basin was a deep-sea slope, the west part was a deep- sea shelf, the central part gradually transitioned to a shallow water shelf (Fig. 5), and the east part changed into fluvial and deltaic deposits (Brookfield et al. 2009; Dashwood and Abbotts 1990; Shanmugam et al. 2000). The west deep-sea slope and shelf became a strongly reducing water mass and formed black shale with considerable 


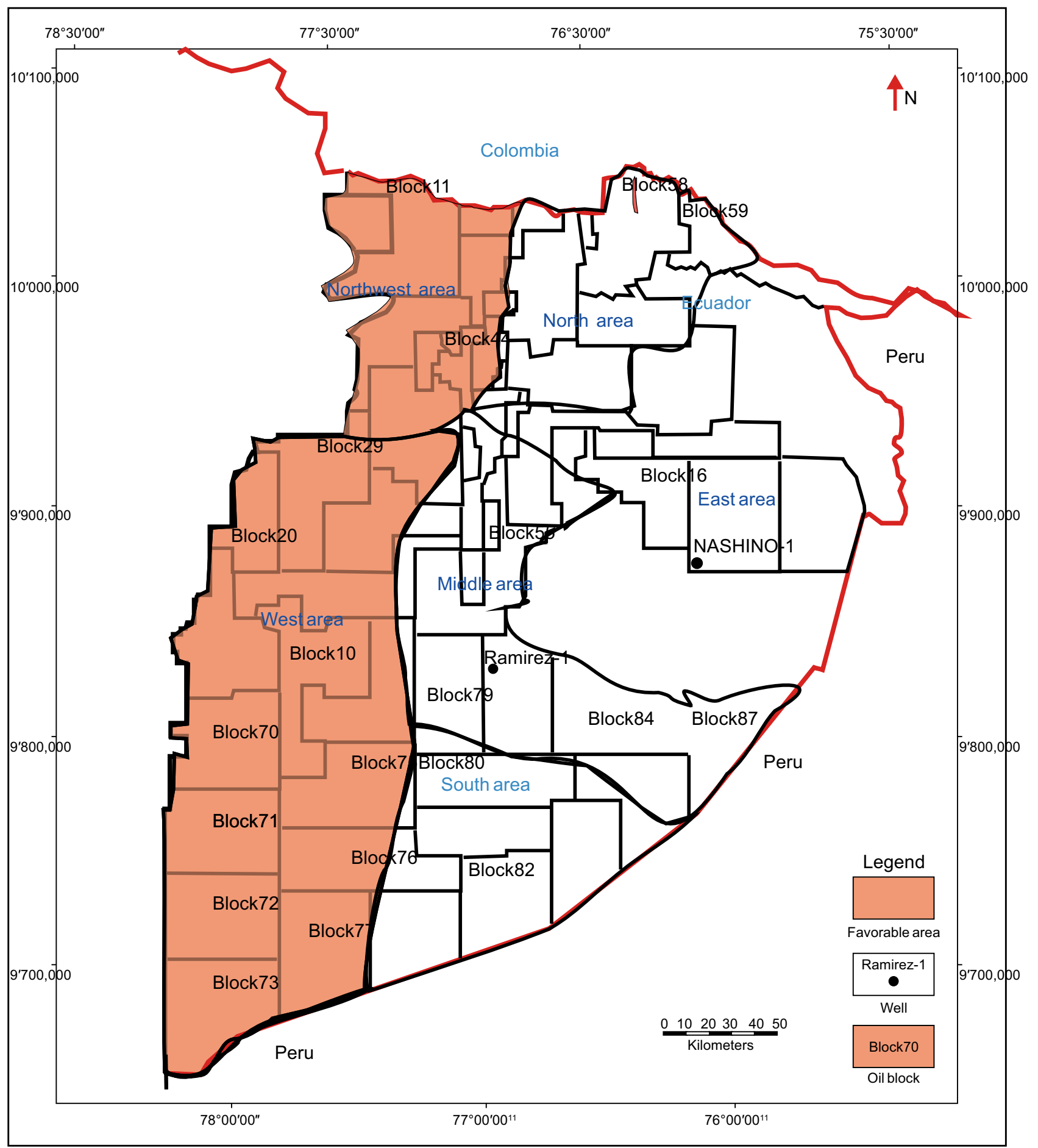

Fig. 4 Predicted favorable areas for exploration of the Lower Napo shale gas in the Oriente Basin

thickness and a certain hydrocarbon generation potential. This set of hydrocarbon source rocks matured and discharged hydrocarbons. The generated oil and gas were transported to the east, entered into the shallow sand bodies and continental sea deltaic sand bodies, and formed a series of oil and gas reservoirs in the central eastern part of the basin.
The northwest and west regions are favorable areas, thereby placing them on the sedimentary facies diagram of the Napo Formation. Figure 5 shows that the northwest and west regions are in the deep-sea slope and continental shelf areas, respectively; thus, the shale thickness in these two areas is considerable. To the east, the sedimentary facies 


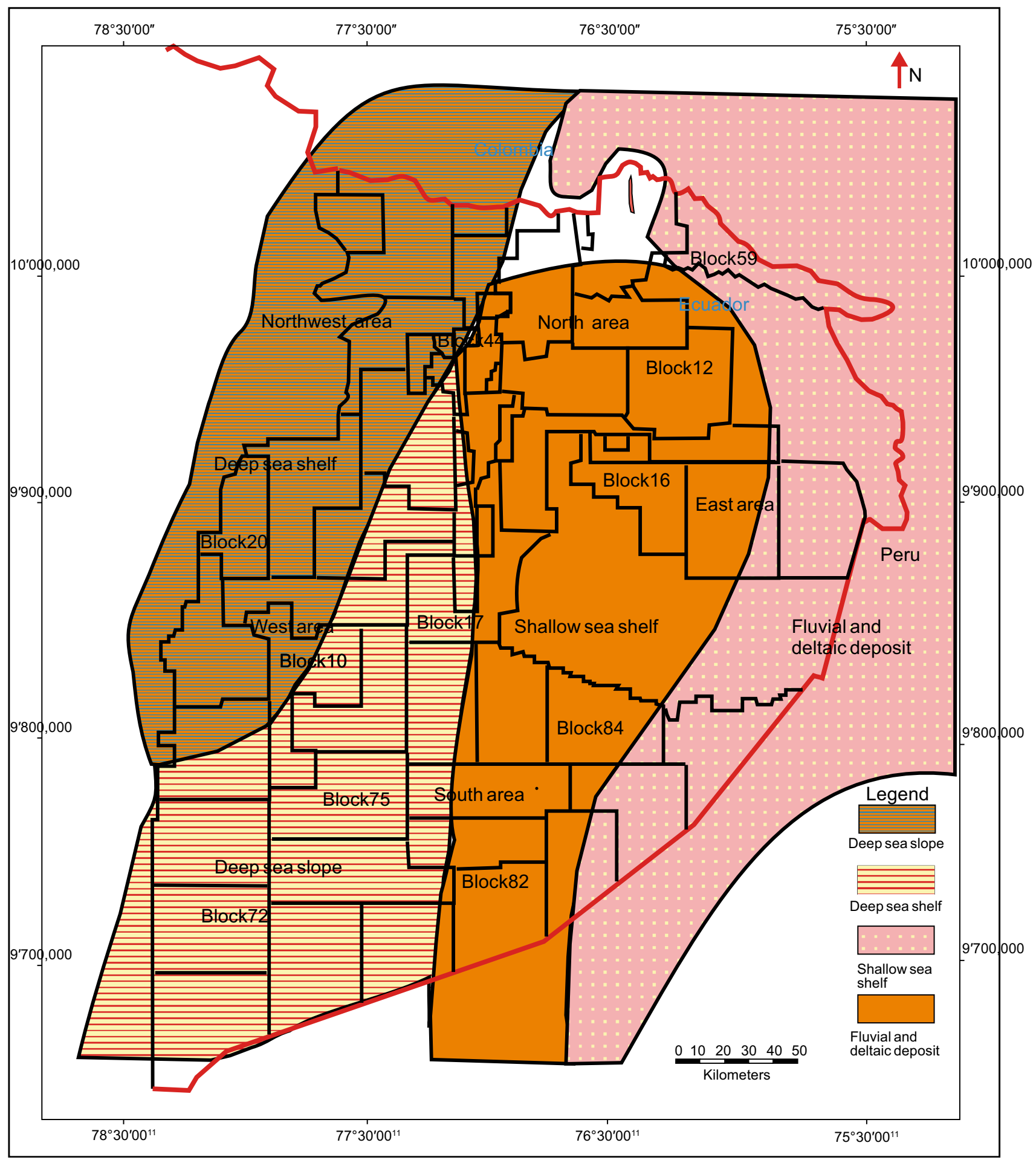

Fig. 5 Sedimentary facies diagram of lower Napo Formation in Oriente Basin (Brookfield et al. 2009)

transition to a shallow water shelf and shale thickness gradually decreases.

\section{Evaluation of the amount of shale gas resources}

According to logging data, the lower Napo Formation in the Oriente Basin is the most favorable potential shale gas reservoir. No related development of shale gas currently 
occurs in Ecuador, and no production data are available to verify the identification results due to limitations in budget and technology. However, preliminary identification results continue to have significance for guiding development. To provide improved bases for the development of shale gas in the Oriente Basin, the amount of shale gas resources in the lower Napo Formation should be assessed. Then, the economic benefits of development should be evaluated. Ultimately, the development of shale gas can be determined on the basis of the amount of available resources.

\subsection{Evaluation method for amount of resources}

Various exploration stages, precision requirements, and available data determine the appropriate evaluation methods. Different techniques require varying parameters, and the methods for obtaining these parameters vary; the final estimation results also differ (Chen et al. 2012, 2015). To select a method, researchers should refer to the exploration stage, geological features, and data conditions of the evaluation area. For the Oriente Basin, shale gas remains in the early stages of exploration, and information is extremely limited. Thus, the analogy method is suitable for evaluating the amount of resources. This method is appropriate for the early exploration stage and requires a small amount of data; it includes area and volume abundance analogies and the Delphi method. From the perspectives of regional geology and reservoir geochemistry, areas with high and low exploration degrees are compared. Inferring unknown regions on the basis of known regions is simple, fast, and highly applicable. The evaluation results have certain guiding significance for an initial exploration (Chen et al. 2012). In this study, on the basis of the known shale reservoir thickness, the volume abundance analogy method is adopted, which is referred to in the literature (Dong et al. 2009). The formula is as follows:

$Q=\alpha \times S \times h \times \rho \times g_{\mathrm{c}}$,

where $Q$ represents the amount of shale gas resource in the forecast area, $\mathrm{m}^{3} ; S$ denotes the distribution area of the gasbearing shale segment in the forecast area, $\mathrm{m}^{2} ; h$ is the shale reservoir thickness in the forecast area, $\mathrm{m} ; \rho$ represents the density of the shale rock, tonne $/ \mathrm{m}^{3} ; g_{\mathrm{c}}$ denotes the shale reservoir gas content of the mature area, $\mathrm{m}^{3} /$ tonne; and $\alpha$ is the similarity coefficient between the forecast and mature areas.

\subsection{Calculation of amount of resources}

As an important resource in the USA, shale gas promotes the "energy independence" of the country (Feng et al. 2016). As the most successful country in shale gas development, the USA has mature technology for this venture.
Therefore, most countries or districts select shale gas reservoirs in North America as the standard areas for evaluating shale gas resources using the analogy method. The organic carbon content, kerogen type, vitrinite reflectance, single-layer shale thickness, brittleness index, porosity, and burial depth of the typical shale gas reservoirs in the USA and the northwest and west regions of the Oriente Basin are thus obtained and compared (Ma et al. 2012). On the basis of these parameters, areas in the USA that are similar to the northwest and west regions of the Oriente Basin are selected. The area resource abundance of typical shale gas reservoirs in the USA is used to determine that of the lower Napo Formation of the northwest and west regions of the Oriente Basin.

The geological analogy parameters of the lower Napo Formation in two favorable areas are obtained from logging and the literature investigation data (Xie et al. 2010).

Statistics regarding the relevant geological analogy parameters of typical shale gas reservoirs in the USA are collected from the previous literature (Curtis 2002; Gao et al. 2016; Fang et al. 2015).

The lower Napo shale in the Oriente Basin belongs to the Mesozoic stratum, which is a structural gas reservoir. For the oil and gas structure formed in the Cretaceous to the Oligocene eras, the lithology is gray and black carbonaceous shale rich in organic matter, and the maturity of organic matter is high. The type of shale gas is biogenic gas, the reservoir property is improved, the brittleness index is high, and the burial depth is moderate. The gas generation condition parameters of the Oriente Basin and the typical US shale gas reservoirs, such as organic carbon content, kerogen type, and vitrinite reflectance, are compared. Then, the gas storage condition parameters, such as porosity, single-layer shale thickness, and burial depth, are also compared.

On the basis of the geological characteristics of the Oriente Basin and the USA, the Woodford shale is the standard area that is most similar to the northwest region and Barnett shale is the standard area that is most similar to the western region. Five among seven geological analogy parameters are similar. For the northwest region, the similar parameters are organic carbon content, kerogen type, vitrinite reflectance, porosity, and burial depth; single-layer shale thickness and brittleness index are dissimilar. For the west region, the similar parameters are organic carbon content, kerogen type, brittleness index, porosity, and burial depth; single-layer shale thickness and vitrinite reflectance are dissimilar (Table 6). Various aspects of the geological conditions in the Oriente Basin are not as effective as the mature shale gas reservoirs in the USA, and this finding is a consensus in the petroleum industry. Therefore, the minimum gas content of the similar standard areas is used as the shale gas area resource abundance of 
Table 6 Comparison of reservoir parameters of the lower Napo Formation in the Oriente Basin and mature shale reservoirs in the USA

\begin{tabular}{|c|c|c|c|c|c|c|c|c|c|}
\hline Basin & Shale name & TOC, $\%$ & $\begin{array}{l}\text { Kerogen } \\
\text { type }\end{array}$ & $\begin{array}{l}\text { Vitrinite } \\
\text { reflectance, } \\
\%\end{array}$ & $\begin{array}{l}\text { Single-layer } \\
\text { shale } \\
\text { thickness, m }\end{array}$ & $\begin{array}{l}\text { Brittleness } \\
\text { index, \% }\end{array}$ & $\begin{array}{l}\text { Porosity, } \\
\%\end{array}$ & $\begin{array}{l}\text { Burial depth, } \\
\mathrm{m}\end{array}$ & $\begin{array}{l}\text { Gas } \\
\text { content, } \\
\mathrm{m}^{3} / \text { tonne }\end{array}$ \\
\hline Fort Worth & Barnett & $2-7$ & II1 & $1-2.1$ & $30.48-182.88$ & $30-50$ & $4-5$ & $1981.2-2591$ & $8.5-9.9$ \\
\hline San Juan & Lewis & $0.45-2.5$ & II, II1 & $1.6-1.88$ & $60.9-570$ & $50-75$ & $3-5.5$ & $914.4-1828.8$ & $0.42-1.27$ \\
\hline Arkema & Fayetteville & $4.0-9.8$ & I, II1 & $1.2-3.0$ & $6.10-60.96$ & $40-70$ & $2-8$ & $305-2133$ & $1.70-6.23$ \\
\hline Arkema & Woodford & $3-7$ & I, II1 & $0.37-4.89$ & $36.57-60.06$ & $50-75$ & $3-9$ & $1828.8-3352.8$ & $5.66-8.5$ \\
\hline Michigan & Antrim & $3-8$ & I & $0.4-0.6$ & $21.34-36$ & $20-41$ & 9 & $182.88-670.56$ & $1.14-4.53$ \\
\hline Illinois & $\begin{array}{l}\text { New } \\
\text { Albany }\end{array}$ & $2-6$ & II1 & $0.4-1.0$ & $15.24-30.48$ & 50 & $10-14$ & $152.4-609.6$ & $1.14-2.27$ \\
\hline Abba La Cilla & Ohio & $0.5-23$ & II1 & $0.4-4$ & $91-610$ & $45-60$ & $2-11$ & $610-1524$ & $1.70-2.83$ \\
\hline Abba La Cilla & Marcellus & $3-12$ & II1 & $0.6-3.0$ & $15.24-60.96$ & $30-60$ & 6 & $1219-2591$ & $1.70-2.83$ \\
\hline Louisiana & Haynesville & $0.5-4.0$ & I, II1 & $2.2-3.0$ & 60.9-91.446 & $35-65$ & $8-9$ & $3200-4115$ & $2.83-9.35$ \\
\hline \multirow[t]{2}{*}{ Oriente } & $\begin{array}{l}\text { Northwest } \\
\text { region }\end{array}$ & $4-6$ & I, II & $0.4-0.6$ & 20.32 & $35-40$ & $3-5$ & 2884 & 5.66 \\
\hline & West region & $4-6$ & I, II & $0.4-0.6$ & 12.9 & $35-40$ & $3-5$ & 2304 & 8.5 \\
\hline
\end{tabular}

Table 7 Calculation results of amount of shale gas resource

\begin{tabular}{lcllllll}
\hline Forecast area & $S, 10^{6} \mathrm{~m}^{2}$ & $h, \mathrm{~m}$ & $\rho$, tonne $/ \mathrm{m}^{3}$ & $g_{\mathrm{c}}$ & $\alpha$ & $Q, 10^{8} \mathrm{~m}^{3}$ & $Q_{\text {total }}, 10^{8} \mathrm{~m}^{3}$ \\
\hline Northwest region & 8220 & 20.32 & 1.9 & 5.66 & 0.714 & 12,800 & 55,500 \\
West region & 28,710 & 12.9 & 1.9 & 8.5 & 0.714 & 42,700 & \\
\hline
\end{tabular}

the Oriente Basin. For the northwest and west regions, the gas contents are 5.66 and $8.5 \mathrm{~m}^{3} /$ tonne, respectively (Table 6).

The preceding analysis results show the calculations of the amount of shale resource of the lower Napo shale in the favorable exploration areas in the Oriente Basin. The existing data are limited, and the lower Napo Formation is assumed to be distributed in the entire northwest and west regions; thus, the total area of the region is regarded as the distribution area of the gas-bearing shale segment in the calculation process. According to the literature, the similarity coefficient $\alpha$ value is 0.714 and the density of the shale rock $\rho$ is 1.9 tonne $/ \mathrm{m}^{3}$ day (Curtis 2002; Gao et al. 2016). The predicted amount of resources is the maximum in the ideal case. Table 7 presents the forecast results. The maximum amount of the shale gas resource of the lower Napo Formation in the favorable exploration areas is approximately $55,000 \times 10^{8} \mathrm{~m}^{3}$, as calculated using the analogy method.

\section{Discussion}

Are the middle and lower Napo Formations shale gas (oil) layers?

In this study, the middle and lower Napo Formations are identified as potential shale gas reservoirs through logging identification. However, this finding has not been verified by actual development results. Ecuador is currently technically and financially constrained and uses shale gas as reserve energy. At present, the exploration and exploitation of shale gas remain in the exploratory stage. No special well test data and other information that indicate whether the Formations contain gas are available. Therefore, the actual gas-bearing situation still requires further development and production data for verification. The possibility that the middle and lower Napo Formations are Shale Gas Formations is discussed as follows. The oil production data of 50 wells in the Oriente Basin are collected, and Table 8 shows the results. The oil-producing blocks (regions) are distributed as follows: east region (blocks 31, 43, and 67), south region (blocks 79, 83, 85, and 86), west region (blocks 48 and 47), north region (blocks 58 and 59), northwest region (blocks 7, 11, 18, 49, 50, and 56), and central region (blocks 10, 15, 16, 21, 61, and 64). Table 8 
Table 8 Oil production statistics of Oriente Basin

\begin{tabular}{|c|c|c|c|c|c|c|c|}
\hline Block & Well name & $\begin{array}{l}\text { Oil production, } \\
\text { barrel/day }\end{array}$ & $\begin{array}{l}\text { Oil-producing } \\
\text { layer }\end{array}$ & Block & Well name & $\begin{array}{l}\text { Oil production, } \\
\text { barrel/day }\end{array}$ & $\begin{array}{l}\text { Oil-producing } \\
\text { layer }\end{array}$ \\
\hline 7 & COCA-1 & 850 & Hollin sandstone & 56 & PARAHUACU-1 & 448 & $\mathrm{~T}$ sandstone \\
\hline 7 & GACELA & 2515 & Hollin sandstone & 56 & DURENO-1 & 244 & $\mathrm{~T}$ sandstone \\
\hline \multirow[t]{2}{*}{7} & CONGA-1 & 490 & $\mathrm{~T}$ sandstone & & & 246 & Hollin sandstone \\
\hline & & 480 & U sandstone & 56 & ATACAPI-1 & 1950 & U sandstone \\
\hline 7 & AUCA SUR & 807 & Hollin sandstone & & & 1840 & $\mathrm{~T}$ sandstone \\
\hline 7 & JAGUAR-1 & 474 & $\mathrm{~T}$ sandstone & 56 & SECOYA-1 & 2574 & U sandstone \\
\hline 10 & VILLANO-2 & 2130 & Hollin sandstone & & & 1665 & $\mathrm{~T}$ sandstone \\
\hline 11 & RUBI-1 & 910 & Hollin sandstone & 56 & AGUARICO-1 & 528 & U sandstone \\
\hline 15 & NAPO-1 & 3386 & $\mathrm{~T}$ sandstone & 56 & SHUSHUFINDI-1 & 2496 & U sandstone \\
\hline 15 & INDILLANA-1 & 3960 & $\mathrm{~T}$ sandstone & & & 2621 & $\mathrm{~T}$ sandstone \\
\hline 15 & ITAYA-1 & 238 & U sandstone & 58 & VICTOR-1 & 5800 & U sandstone \\
\hline \multirow[t]{3}{*}{15} & JIVINOA-1 & 1872 & $\mathrm{~T}$ sandstone & & & 3817 & U sandstone \\
\hline & & 950 & Hollin sandstone & & & 1008 & $\mathrm{~T}$ sandstone \\
\hline & & 987 & U sandstone & 59 & TIPISHCA-1 & 1677 & $\mathrm{~T}$ sandstone \\
\hline \multirow[t]{2}{*}{15} & PRIMAVERA-1 & 211 & U sandstone & & & 2266 & U sandstone \\
\hline & & 148 & $\mathrm{~T}$ sandstone & 61 & ANACONDA & 874 & Hollin sandstone \\
\hline 16 & BOGI & 1000 & Hollin sandstone & 64 & YUCA-1 & 520 & Hollin sandstone \\
\hline \multirow[t]{2}{*}{16} & AMO-1 & 415 & Hollin sandstone & & & 50 & $\mathrm{~T}$ sandstone \\
\hline & & 547 & TENA sandstone & 67 & IRO-1 & 2101 & U sandstone \\
\hline \multirow[t]{2}{*}{16} & DAIMI-1 & 1754 & M1 sandstone & & & 1439 & M1 sandstone \\
\hline & & 534 & U sandstone & 67 & CAPIRON-1 & 908 & M1 sandstone \\
\hline 16 & GIUTA-1 & 154 & U sandstone & & & 249 & Hollin sandstone \\
\hline 18 & PATA-1 & 814 & $\mathrm{~T}$ sandstone & 67 & SHIRIDUNO-1 & 3400 & Hollin sandstone \\
\hline 21 & MONO-1 & 1069 & Hollin sandstone & & & 384 & U sandstone \\
\hline 21 & YURALPA-1 & 2350 & Hollin sandstone & & & 336 & U sandstone \\
\hline \multirow[t]{2}{*}{21} & DAYUNO-1 & 710 & M2 limestone & & & 480 & M1 sandstone \\
\hline & & 250 & Hollin sandstone & & & 250 & M2 sandstone \\
\hline \multirow[t]{2}{*}{31} & ISHPINGO & 3058 & M1 sandstone & 67 & AMANT-1 & 639 & U sandstone \\
\hline & & 1146 & $\mathrm{~T}$ sandstone & & & 963 & M1 sandstone \\
\hline \multirow[t]{2}{*}{43} & TANBOCOCHA-1 & 1800 & TENA sandstone & 79 & CURARAY-1 & 296 & M1 sandstone \\
\hline & & 2895 & M1 sandstone & & & 254 & U sandstone \\
\hline 47 & SACHA & 2310 & Hollin sandstone & & & 186 & $\mathrm{~T}$ sandstone \\
\hline 47 & HUAMAYAO-1 & 1200 & TENA sandstone & & & 896 & Hollin sandstone \\
\hline \multirow[t]{2}{*}{47} & PAYAMINO-1 & 1510 & Hollin sandstone & 79 & DANTA & 919 & U sandstone \\
\hline & & 160 & U sandstone & & & 1800 & U sandstone \\
\hline \multirow[t]{2}{*}{48} & PUCUNA-1 & 740 & Hollin sandstone & 83 & RAMIREZ-1 & 501 & U sandstone \\
\hline & & 230 & $\mathrm{~T}$ sandstone & 85 & HUITO-1 & 163 & M1 sandstone \\
\hline \multirow[t]{2}{*}{48} & PUCUNA-1 & 740 & Hollin sandstone & 86 & AMAZONAS-1 & 962 & U sandstone \\
\hline & & 230 & $\mathrm{~T}$ sandstone & 86 & BALSAURA-1 & 1010 & Hollin sandstone \\
\hline 49 & BERMEJOSUR & 754 & Hollin sandstone & & & 1674 & M1 sandstone \\
\hline 50 & CHARAPA-1 & 753 & T sandstone & & & 1057 & U sandstone \\
\hline
\end{tabular}

shows that oil is mainly derived from the $\mathrm{U}, \mathrm{T}, \mathrm{M} 1$, and M2 sandstones of the Napo Formation and Hollin sandstone. Two main types of rocks can be used as hydrocarbon source rocks, namely argillaceous and carbonate rocks. Argillaceous rocks are mainly mudstone and shale rich in organic matter or clay rocks. Carbonate rocks are mainly gray, deep gray bituminous, biogenic, and argillaceous limestones. The T, U, M1, and M2 sandstones and the Hollin Formation on the upper part of the Napo Formation are merely favorable reservoirs and are not hydrocarbon 
source rocks themselves. The oil they contain has probably been generated by other hydrocarbon source rocks and transported to these reservoirs.

Results of previous studies have shown that the main hydrocarbon source rocks of the Oriente Basin are the Cretaceous middle Napo, lower Napo, and TriassicJurassic Santiago Formations. From the perspective of oil and gas migration, the Santiago Formation is not likely to have been a source rock that generated oil and then gas migrated to the Napo Formation. First, in the vertical direction, the Santiago Formation in the Triassic to the lower Jurassic strata is buried deeply at $4000 \mathrm{~m}$. Therefore, this Formation is far from being the oil-producing layer. Oil and gas migration is controlled by multiple factors, such as dynamic size, tectonic condition, oil and gas properties, and change in lithofacies. Thus, the long-distance migration of oil and gas is difficult; the actual oil and gas migration distance is generally not too long. Second, in the horizontal direction, the Triassic-Jurassic Santiago Formation is mainly distributed in the southern part of the basin (Gaibor et al. 2008). The lateral migration distance for the Santiago Formation as source rock is too long, and migration difficulty is considerable. Therefore, the Santiago Formation could not have been the main source rock that supplied oil and gas to the Napo and Hollin Formations. Meanwhile, the lower Napo shale Formation is beneath the U, T, M1, and M2 sandstones and above the Hollin sandstone. The distance is near; thus, this Formation is likely to have been the source rock that generated the oil and gas that migrated to the reservoirs. The middle Napo Formation is between the $\mathrm{U}$ and $\mathrm{T}$ sandstones and may have also served as a source rock. However, if the middle and lower Napo Formations are the hydrocarbon source rocks, then the oil and gas they generated could not have completely migrated to other horizons; that is, residual oil and gas should still be present. Therefore, the middle and lower Napo Formations are likely to be enriched in shale gas or oil.

\section{Conclusions}

1. The TOC and $R_{\mathrm{O}}$ values of lower Napo shale are suitable for a source rock, and the burial depth, accumulated thickness, brittle mineral content, porosity value, and research data integrity all meet the development conditions of a shale gas reservoir. Therefore, the lower Napo shale is selected from the five sets of potential hydrocarbon source rocks, namely the Macuma Formation, the Santiago Formation, lower Napo shale, middle Napo shale, and the Tiyuyacu Formation. The logging response characteristics of lower and middle Napo shales show that the caliper logging exhibits enlargement, the Sp logging shows the base value, and the Gr, resistivity, and acoustic logging values are high. These results mean that the two layers comprise a shale gas reservoir. The middle and lower Napo shale Formations are regarded as the shale-gas-bearing layers on the basis of the quantitative analysis of logging data. Furthermore, the GR and resistivity logging values of the lower Napo shale are higher than those of the middle Napo shale. Combining the evaluation of the geological parameters with the logging response characteristics, the lower Napo shale is eventually considered the research target layer.

2. The thickness of lower Napo shale is obtained on the basis of the logging data of typical wells in different blocks of the basin. The regions with the largest sedimentary thickness are selected, and the west and northwest regions are considered the favorable areas for shale gas accumulation. The study of the sedimentary tectonic setting of the favorable areas shows that the two favorable areas were in the deep-sea shelf and slope environments, which are the most favorable environments for the formation of dark hydrocarbon source rocks rich in organic matter. The oil and gas generated by the hydrocarbon source rocks not only became the source of oil in several oil fields in the east and south of the study area but also formed favorable shale gas accumulation areas after migration.

3. Important geological analogy parameters of typical shale reservoirs in the USA are compared with those of the lower Napo Formation in the favorable areas. The Barnett shale is the standard area that is most similar to the western region; five out of seven geological analogy parameters are similar. The standard area that is most similar to the northwest region is Woodford shale for the same reason. The gas contents of the similar standard areas are used to calculate the shale gas resources of the favorable areas through the volume method, and the maximum value is approximately $55,500 \times 10^{8} \mathrm{~m}^{3}$. The calculation of the amount of resources quantitatively evaluates the potential of shale gas resources in the Oriente Basin.

Open Access This article is distributed under the terms of the Creative Commons Attribution 4.0 International License (http://creative commons.org/licenses/by/4.0/), which permits unrestricted use, distribution, and reproduction in any medium, provided you give appropriate credit to the original author(s) and the source, provide a link to the Creative Commons license, and indicate if changes were made. 


\section{References}

Brookfield ME, Hemmings DP, van Straaten P. Paleoenvironments and origin of the sedimentary phosphorites of the Napo Formation (Late Cretaceous, Oriente Basin, Ecuador). J S Am Earth Sci. 2009;28(2):180-92. https://doi.org/10.1016/j.jsames. 2009.02.004.

Chen XJ, Bao SJ, Hou DJ, et al. Methods and key parameters of shale gas resource evaluation. Pet Explor Dev. 2012;39(5):605-10. https://doi.org/10.1016/S1876-3804(12)60082-2.

Chen Z, Osadetz KG, Chen X. Economic appraisal of shale gas resources, an example from the Horn River shale gas play, Canada. Pet Sci. 2015;12(4):712-25. https://doi.org/10.1007/ s12182-015-0050-9.

Christophoul F, Baby P, Davila C. Stratigraphic responses to a major tectonic event in a foreland basin: the Ecuadorian Oriente Basin from Eocene to Oligocene times. Tectonophysics. 2002;345(1-4):281-98. https://doi.org/10.1016/S00401951(01)00217-7.

Curtis J. Fractured shale-gas systems. AAPG Bull. 2002;86(11):1921-38. https://doi.org/10.1306/61EEDDBE173E-11D7-8645000102C1865D.

Dashwood MF, Abbotts IL. Aspects of the petroleum geology of the Oriente Basin, Ecuador. Geol Soc. 1990;50(1):89-117. https:// doi.org/10.1144/GSL.SP.1990.050.01.06.

Dong DZ, Cheng KM, Wang SQ, et al. An evaluation method of shale gas resource and its application in the Sichuan basin. Nat Gas Ind. 2009;29(5):33-9. https://doi.org/10.3787/j.issn.1000-0976. 2009.05.007 (in Chinese).

Estupiñan J, Marfil R, Scherer M, Permanyer A. Reservoir sandstones of the Cretaceous Napo Formation $U$ and $T$ members in the Oriente Basin, Ecuador: links between diagenesis and sequence stratigraphy. J Pet Geol. 2010;33(3):221-45. https://doi.org/10. 1111/j.1747-5457.2010.00475.x.

Fang DZ, Zeng H, Wang N, et al. Study on high production factors of high-pressure shale gas from Haynesville Shale Gas development data. Oil Drill Prod Technol. 2015;37(2):58-62. https://doi. org/10.13639/j.odpt.2015.02.016 (in Chinese).

Feng ZQ, Huang SP, Wu W, et al. The development history of shale gas in United States and coal-derived gas in China and enlightenment to China. Nat Gas Geosci. 2016;27(3):449-60. https://doi.org/10.11764/ji.ssn.1672-1926.2016.03.0449 (in Chinese).

Gaibor J, Hochuli PA, Winkler W, et al. Hydrocarbon source potential of the Santiago Formation, Oriente Basin, SE of Ecuador. J S Am Earth Sci. 2008;25(2):145-56. https://doi.org/ 10.1016/j.jsames.2007.07.002.

Gao HX, Wang XL, Yan W, et al. Lower limit of effective thickness of shale gas: a case from the Wufeng and Longmaxi Formations in Fuling shale gas field. Fault-Block Oil Gas Field. 2016;23(4):434-7. https://doi.org/10.6056/dkyqt201604006 (in Chinese).

Gross D, Sachsenhofer RF, Bechtel A, et al. Organic geochemistry of Mississippian shales (Bowland Shale Formation) in central Britain: implications for depositional environment, source rock and gas shale potential. Mar Pet Geol. 2015;59:1-21. https://doi. org/10.1016/j.marpetgeo.2014.07.022.

Jiang S, Feng YL, Chen L, et al. Multiple-stacked Hybrid Plays of lacustrine source rock intervals: case studies from lacustrine basins in China. Pet Sci. 2017;14(3):459-83. https://doi.org/10. 1007/s12182-017-0179-9.

Misch D, Gross D, Mahlstedt N, et al. Shale gas/shale oil potential of Upper Visean Black Shales in the Dniepr-Donets Basin (Ukraine). Mar Pet Geol. 2016;75:203-19. https://doi.org/10. 1016/j.marpetgeo.2016.04.017.

Ma ZZ, Xie YF, Chen HP, et al. Hydrocarbon accumulation features and exploration direction selection: taking $M$ block of the Oriente Basin, Ecuador as an example. Nat Gas Geosci. 2014;25(3):379-87. https://doi.org/10.11764/j.issn.1672-1926. 2014.03.0379 (in Chinese).

Ma ZZ, Chen HP, Xie YF, et al. Division and resources evaluation of hydrocarbon plays in the Putumayo-Oriente-Maranon Basin, South America. Pet Explor Dev. 2017;44(2):247-56. https://doi. org/10.1016/S1876-3804(17)30027-7 (in Chinese).

Ma N, Hou DJ, Bao SJ, et al. Petroleum geology and recovery efficiency. Pet Explor Dev. 2012;19(6):25-9. https://doi.org/10. 13673/j.cnki.cn37-1359/te.2012.06.006 (in Chinese).

Oztürk SS, Demirel IH, Günay Y. Petroleum source rock potential of the Silurian Dadas shales in the Hazro and Korudağ regions of Southeast Anatolia, Turkey. Mar Pet Geol. 2016;75:53-67. https://doi.org/10.1016/j.marpetgeo.2016.04.007.

Song Y, Li Z, Jiang L, et al. The concept and the accumulation characteristics of unconventional hydrocarbon resources. Pet Sci. 2015;12(4):563-72. https://doi.org/10.1007/s12182-015-0060-7.

Stow DAV, Huc AY, Bertrand P. Depositional processes of black shales in deep water. Mar Pet Geol. 2001;18:491-8. https://doi. org/10.1016/S0264-8172(01)00012-5.

Shanmugam G, Poffenberger M, Toro Alava J. Tide-dominated estuarine facies in the Hollin and Napo Formations, Sacha field, Oriente Basin, Ecuador. AAPG Bull. 2000;84(5):652-82. https:// doi.org/10.1306/C9EBCE7D-1735-11D7-8645000102C1865D.

Torres ME, Frydman M, Goddyn X et al. Geomechanics aspects of the Oriente Basin, Ecuador, South America. SPE 138914. 2010;12:1-19. https://doi.org/10.2118/138914-MS.

Wu CJ, Zhang MF, Ma WY, et al. Organic matter characteristics and sedimentary environment of the Lower Cambrian Niutitang shale in southeastern Chongqing. Nat Gas Geosci. 2014;25(8):1267-74. https://doi.org/10.11764/j.issn.1672-1926. 2014.08.1267 (in Chinese).

Xie YF, Ji HC, Su YD, et al. Petroleum geology and exploration potential of Oriente-Maranon Basin. Pet Explor Dev. 2010;37(1):51-6. https://doi.org/10.1016/S18763804(10)60014-6.

Xiao XM, Wei Q, Gai HF. Main controlling factors and enrichment area evaluation of shale gas of the Lower Paleozoic marine strata in south China. Pet Sci. 2015;12(4):573-86. https://doi.org/10. 1007/s12182-015-0057-2.

Yang XB, Yang ZF, Xie B, et al. Log interpretation and evaluation of shale gas reservoirs. Nat Gas Ind. 2012;32(9):33-6. https://doi. org/10.3787/j.issn.1000-0976.2012.09.007 (in Chinese).

Yan W, Wang JB, Liu S, et al. Logging identification of the Longmaxi mud shale reservoir in the Jiaoshiba area, Sichuan Basin. Nat Gas Ind. 2014;1(2):230-6. https://doi.org/10.1016/j. ngib.2014.11.016 (in Chinese).

Zou CN, Dong DZ, Wang YM, et al. Shale gas in China: characteristics, challenges and prospects(1). Pet Explor Dev. 2015;42(6):689-701. https://doi.org/10.11698/ped.2015.06.01 (in Chinese). 